\title{
Low cost NodeMcu based development water rocket measurement system applied to STEM education
}

\author{
Andi Susilo*1, Yasmiati ${ }^{2}$, Ahmad Apandi ${ }^{3}$ \\ Informatics Engineering, Information Technology, Universitas Respati Indonesia, \\ Bambu Apus I St. No.3, Cipayung East Jakarta 13890, Indonesia \\ *Corresponding author, e-mail: as@fti.urindo.ac.id¹', yasmiati@fti.urindo.ac.id², \\ ahmad.apandi@fti.urindo.ac.id ${ }^{3}$
}

\begin{abstract}
Water rockets have become one of learning tools for STEM Education in schools. Generally water rockets make in school activity have no parachute load, altitude, and velocity measurement. Rocket can go any direction and also will cause hard collision to the ground that break the high speed rocket. It will take time and need more cost to make a new one for students. This study propose the low cost NodeMcu based water rocket measurement system to solve the problem. Altitude and velocity measurement are added and deployment system to release the parachute to make water rocket fall to the ground smoothly. Smartphone application used to monitor altitude and velocity of water rocket. Variables consist of water volume and air pressure. Five experiments had been conducted and recorded. The result found that the system could calculate Altitude, Velocity, and Deployment System also could release the parachute automatically in Coasting Descent position.
\end{abstract}

Keywords: NodeMcu, water rocket, altitude, deployment system, STEM Education

Copyright $\odot 2019$ Universitas Ahmad Dahlan. All rights reserved.

\section{Introduction}

STEM education is an educational activities in the field of Science, Technology, Engineering, and Mathematics [1]. Many Middle or High School and Universities have visions of STEM emphazised on workforce development and research to meet the needs of local and regional industries, national security, and efforts to be competitive in a global market [2]. National Aeronautics and Space Administration (NASA) stated model rocketry is fully representative of the scientific process and the engineering applications of real world challenges [3]. Water rocket activity is one alternative to apply STEM Education in Indonesia.

The events of list National and International Water Rocket Competition for last three years can be seen in Table 1. Science Center (PP-IPTEK) under Ministry of Research Technology (Kemenristek) has organized Regional and National Water Rocket Competition (KRAN) Events since 2005. In 2017 Ministry of Research Technology merged with Directorate of Higher Education (DIKTI) and the new name of organization is Kemenristekdikti. In international scale, Indonesia's student team had $3^{\text {rd }}$ place winner from WRE in 2017. In national scale, the number of participant and city for KRAN increases every year from 2015 to 2017. It is indicators that the students in Indonesia have high interest in Space field especially Rocket Science [4-6].

Space Education Working Group (SEWG) is one of four working groups under Asia Pacific Regional Space Agency Forum (APRSAF) regularly arranges water rocket Competition Event (WRE) [7]. APRSAF was established in 1993 to enhance space activities in the Asia-Pacific region. This competition emphasizes at capability of the rocket to achieve as close as possible to the landing target. The launch position will be placed $60 \mathrm{~m}$ from target. Launcher, air pump, and all materials to make rocket will be provided by organizer. Students will not permit to bring their pre-made water rocket or launcher from their home countries. Each student should make one (1) water rocket in two (2) hours. Each student has challenge to make his/her own creative design of water rocket.

The problems can be identified namely (1) Water Rocket will break when bumping the ground in high velocity, it will take times and need more cost to make or fix them; (2) There is no electronic equipments to measure altitude and velocity in real time and also system to release the parachute to cover the water rocket from damages. In the next section is discussion about 
our proposal to model water rocket competition by adding altitude and velocity as aspects for the result. Finally, step to build water rocket measurement system that use low cost nodeMcu as a microcontroller to measure altitude, velocity, and also deployment system with the main function to release the parachute.

Table 1. National and International Water Rocket Competition

\begin{tabular}{|c|c|c|c|c|c|c|c|c|c|c|c|}
\hline & \multicolumn{5}{|c|}{ National } & \multicolumn{5}{|c|}{ International } & Result \\
\hline Year & Date & Location & $\begin{array}{l}\text { Number of } \\
\text { Participant }\end{array}$ & $\begin{array}{c}\text { Number } \\
\text { of City }\end{array}$ & Organization & & Location & $\begin{array}{l}\text { Number of } \\
\text { Participant }\end{array}$ & $\begin{array}{c}\text { Number } \\
\text { of City }\end{array}$ & Organization & \\
\hline 2017 & $\begin{array}{l}29-30 \\
\text { Sep. } \\
2017\end{array}$ & Serpong & 122 & 15 & Kemenristekdikti & $\begin{array}{l}11-12 \\
\text { Nov. } \\
2017\end{array}$ & $\begin{array}{l}\text { Bengaluru, } \\
\text { India }\end{array}$ & 53 & 11 & APRSAF & $3 r d$ \\
\hline 2016 & $\begin{array}{c}8-9 \\
\text { Oct. } \\
2016 \\
3-4\end{array}$ & Serpong & 106 & 13 & Kemenristek & $\begin{array}{l}12-13 \\
\text { Nov. } \\
2016 \\
28-29\end{array}$ & $\begin{array}{l}\text { Laguna, } \\
\text { Philippines }\end{array}$ & 54 & 13 & APRSAF & $\begin{array}{l}\text { 2nd, } \\
\text { 3rd }\end{array}$ \\
\hline 2015 & $\begin{array}{l}\text { Oct. } \\
2015\end{array}$ & Serpong & 97 & 11 & Kemenristek & $\begin{array}{l}\angle 8-\angle 9 \\
\text { Nov. } \\
2015\end{array}$ & $\begin{array}{c}\text { Bali, } \\
\text { Indonesia }\end{array}$ & 58 & 13 & APRSAF & 6th \\
\hline
\end{tabular}

Legend:

APRSAF

: Asia Pacific Regional Space Agency Forum

Participant age : 11-16 years old for National and 12-16 years old for International

\section{Research Method}

As described before in first section, WRE organized by APRSAF focus on capability of the rocket to reach the landing target as a result. Figure 1 shows the model of water rocket competition arranged by APRSAF [7]. There are six (6) launchers will be placed and they will be used by each participating country alternately. Six (6) water rockets will lauch at once from $60 \mathrm{~m}$ distance to the landing target. The highest scores will achieve when the rocket fall down in the GOLD Band area, $5 \mathrm{~m}$ radius from bull's eye. Different level scores will calculate when the rockets position is in SILVER Band, $7 \mathrm{~m}$ radius and BRONZE Band, $10 \mathrm{~m}$ radius. No score achieves when a rocket is in OUT of range area. Launchers will set in certain elevation degree to move the rocket through optimal ellipse route until the landing target reached.

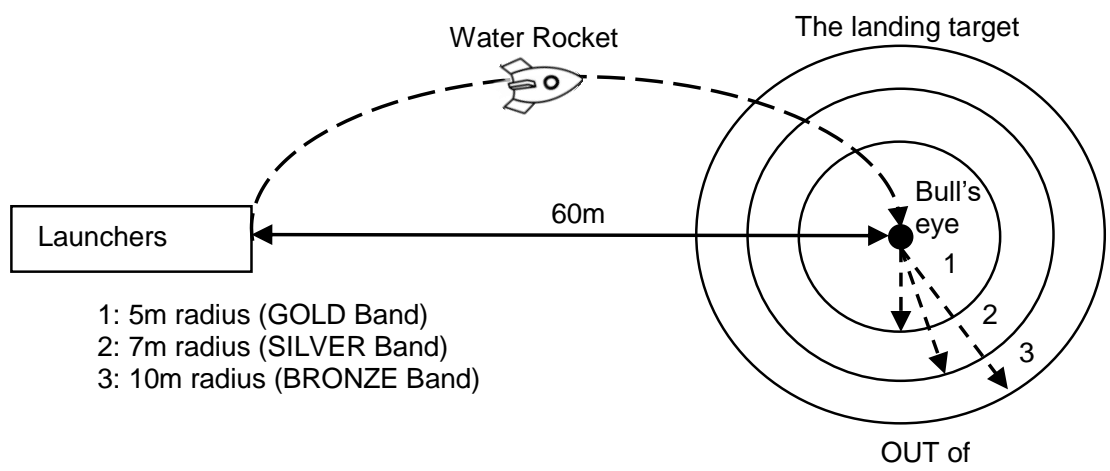

Figure 1. APRSAF model of water rocket competition

Figure 2 shows the proposed Altitude, Velocity, and Parachute (AVP) model of water rocket competition to add altitude, velocity, and parachute deployment system to collect the score. The distance is reduced $20 \mathrm{~m}$ between Launchers and Bull's eye, so the distance $40 \mathrm{~m}$ enables water rocket to fly and land in the Landing Target. The water rocket will reach the highest velocity in the position between Lauch and Powered Ascent. Altitude and velocity are increasing, Acceleration is constant positive. In the Coasting Ascent, the thrust of water rocket will decrease constantly [8]. Altitude is increasing, Velocity is decreasing up, and Acceleration is constant negative. The Apogee position indicates water rocket is in Maximum Altitude, the value of Velocity is zero, and Acceleration is constant negative. Table 2 lists the complete changes of Altitude, Velocity, and Acceleration values in possible any position of water rocket. 


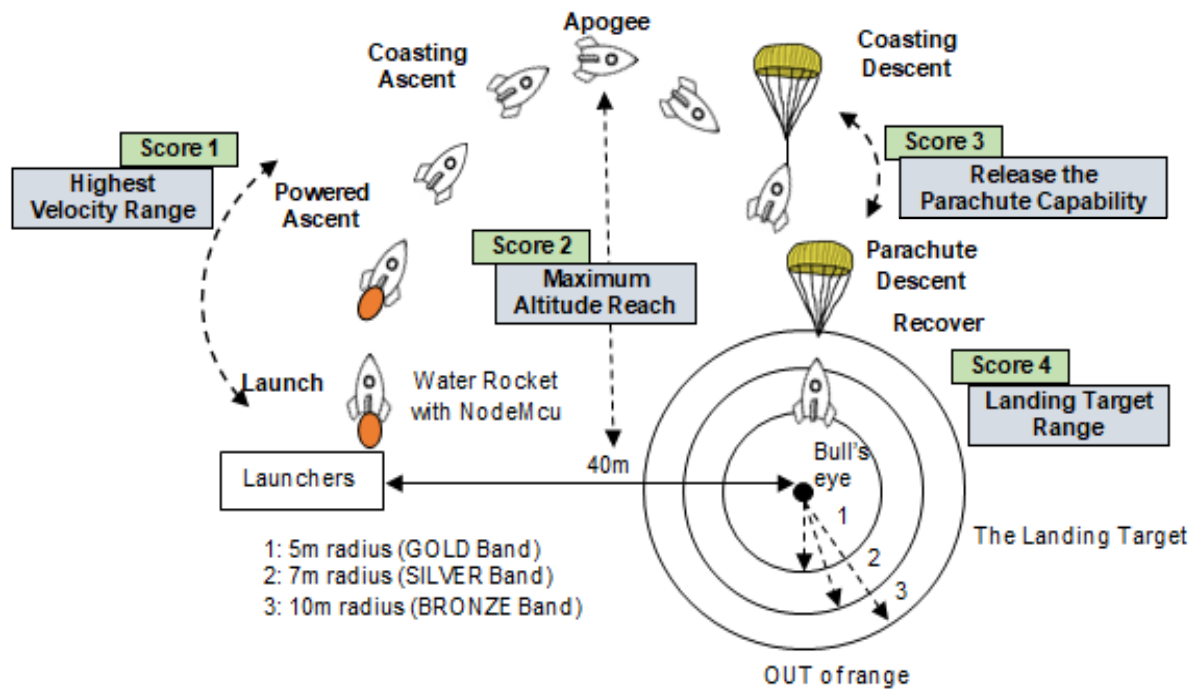

Figure 2. Proposed AVP model of water rocket competition

Table 2. Position and Measurement Variables of Water Rocket

\begin{tabular}{|c|c|c|c|c|c|c|c|}
\hline Measurement & Launch & $\begin{array}{c}\text { Powered } \\
\text { Ascent }\end{array}$ & $\begin{array}{l}\text { Coasting } \\
\text { Ascent }\end{array}$ & Apogee & $\begin{array}{l}\text { Coasting } \\
\text { Descent }\end{array}$ & $\begin{array}{c}\text { Parachute } \\
\text { Descent }\end{array}$ & Recovery \\
\hline Altitude & Increasing & Increasing & Increasing & Maximum & Decreasing & Decreasing & Zero \\
\hline Velocity & $\begin{array}{l}\text { Increasing } \\
\text { Up }\end{array}$ & $\begin{array}{l}\text { Increasing } \\
\text { Up }\end{array}$ & $\begin{array}{c}\text { Decreasing } \\
\text { Up }\end{array}$ & Zero & $\begin{array}{l}\text { Increasing } \\
\text { Down }\end{array}$ & $\begin{array}{l}\text { Constant } \\
\text { Down }\end{array}$ & Zero \\
\hline Acceleration & $\begin{array}{l}\text { Constant } \\
\text { Positive }\end{array}$ & $\begin{array}{l}\text { Constant } \\
\text { Positive }\end{array}$ & $\begin{array}{l}\text { Constant } \\
\text { Negative }\end{array}$ & $\begin{array}{l}\text { Constant } \\
\text { Negative }\end{array}$ & $\begin{array}{l}\text { Constant } \\
\text { Negative }\end{array}$ & Zero & Zero \\
\hline
\end{tabular}

Four scores will be collected from one launch of a water rocket in sequence order (see Table 3 and Figure 2 as comparison). Symbol check $(\sqrt{ })$ means value must be measured to add for score, while symbol minus (-) means values are not important to be measured in section of Score criterias. As an exception the minus symbol is placed in all columns of Score 4, because this score will be obtained in Recovery state after the water rocket fall and land in The Landing Target and the score collects based on Band area.

Score 1: Highest Velocity Range is the value taken for the first time. The best value of Score 1 can get when the water rocket start to lauch and will end when water rocket just passed Power Ascent position; Score 2: Maximum Altitude Reach indicates altitude of water rocket in Apogee, water rocket is in zero velocity for a while; Score 3: Release Parachute Capability when the deployment system succeed to release the parachute from capsule will result Success (S) or Not Success (NS) score; Finally Score 4: Landing Target Range, the value depends on the water rocket position in the Landing Target for $5 \mathrm{~m}, 7 \mathrm{~m}$, and $10 \mathrm{~m}$ radius. The sum of points of Score 1, Score 2, Score 3, and Score 4 produce the total score for one launch in each participant group.

Table 3. Score Criteria and Measurement Variables

\begin{tabular}{|c|c|c|c|c|}
\hline \multirow[b]{2}{*}{ Measurement variables } & \multicolumn{4}{|c|}{ Score criteria } \\
\hline & $\begin{array}{l}\text { Score } 1 \text { : } \\
\text { Highest Velocity } \\
\text { Range |(meter/s) }\end{array}$ & $\begin{array}{c}\text { Score 2: } \\
\text { Maximum Altitude } \\
\text { Reach (meter) }\end{array}$ & $\begin{array}{l}\text { Score 3: } \\
\text { Release the Parachute } \\
\text { Capability (S or NS) }\end{array}$ & $\begin{array}{c}\text { Score 4: } \\
\text { Landing Target } \\
\text { Range (Band) }\end{array}$ \\
\hline Altitude & & $\sqrt{ }$ & - & - \\
\hline Velocity & $\sqrt{ }$ & - & - & - \\
\hline Deployment System & - & - & $\sqrt{ }$ & - \\
\hline
\end{tabular}

\subsection{Water Rocket Measurement System Design}

Basic water rocket components can be seen at Figure 3. Water Rocket Measurement System consists of system to calculate Altitude, Velocity, and Deployment System as shown in 
Figure 4. All main parts include NodeMcu Development Kit, sensors, servo motor, modem, battery, and parachute placed in the Payload, except Reed switch sensor is installed in the body.

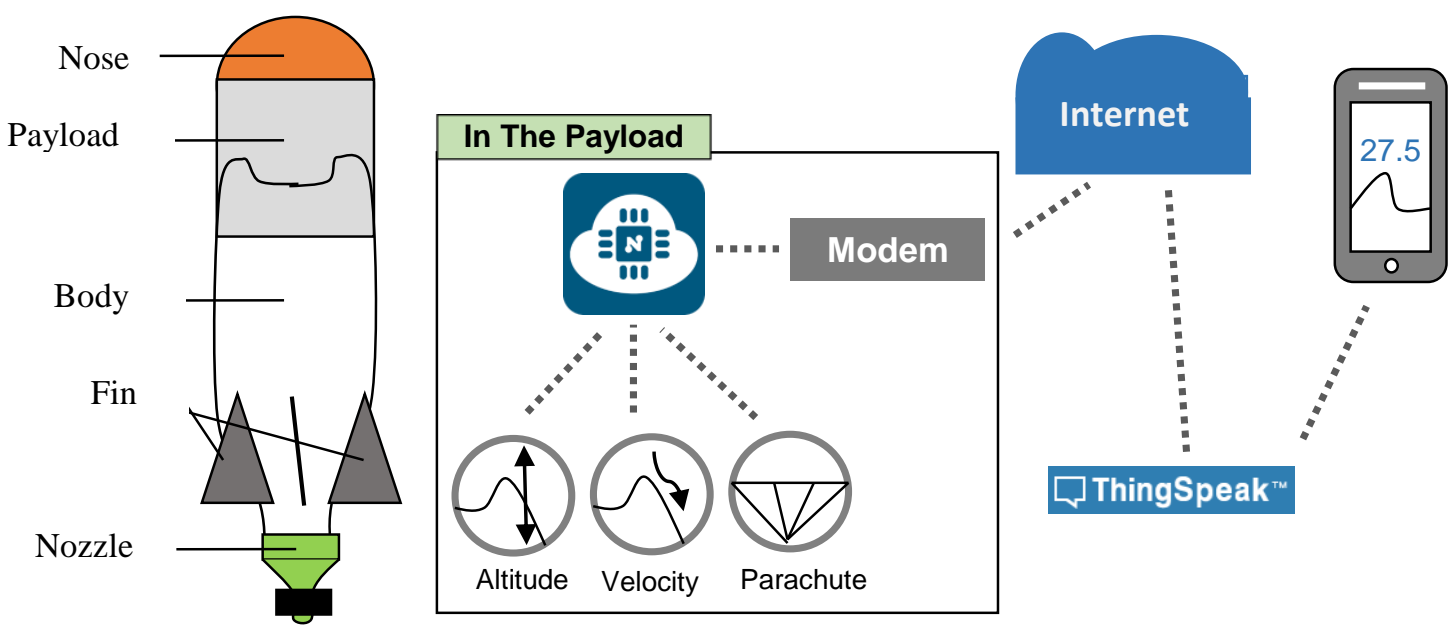

Figure 3. Structure of water rocket

Figure 4. Water rocket measurement system design

NodeMcu Development Kit ESP8266 Wifi Module connected to Internet via modem. It is ideal board for reasonable price to support Internet of Things (IOT) application. IoT is an enabler for developing new intelligent applications and services [9]. The general approach is to collect data from all of the different devices by a push or a pull approach. After data has been collected it can be stored and analyzed by the platform [10]. Although the NodeMcu is easy to use, the current consumption is the highest being a major drawback if the low energy consumption is of primary importance [11]. BMP180 sensor data are sent privately to the cloud via Thing Speak [12]. Sensor data will be processed to calculate Altitude and Velocity, when the water rocket reached the Apogee position, the deployment system will automatically release the parachute. The sensors share the collected data over the Internet for processing by the processing unit. The processing result is communicated to decision making and action invoking system to invoke the appropriate action [13]. Through smartphone ThingSpeak Channel is accessed to see visualization of the current data and calculate new data from sensor. The important element of ThingSpeak activity is the channel which contains data fields, location fields, and status fields [14]. Thingspeak communicate with the assistance of net affiliation which works concerning as associate degree info packet carrier between the connected "things". Thingspeak cloud also retrieve, save/store, analyze, observe and withdraw at the detected info from the connected detector to NodeMcu [15].

\subsection{System Implementation}

After finishing design phase the next step is to build the complete system. It is necessary to make sure that the size and weight of all part of the system meet and fit the space of payload requirement. The water rocket must be able to bring all of things with that weight and fly normally. The cables connection of each part include NodeMcu ESP8266, BMP180, modem, and battery. Two of $1.5 \mathrm{~L}$ bottles are modified by cutting into two parts to make capsules and module for payload. Parts of Measurement System can be seen at Figure 5. Figure 6 shows final installation of water rocket measurement system that place in Payload.

Electronic circuit for water rocket measurement system in schematic can be seen at Figure 7 and list of electronic components to develop the system is presented in Table 4. Modem is not included in the list because modem is external device to make Internet connection. Lithium lon light weight battery is used to power the system. 


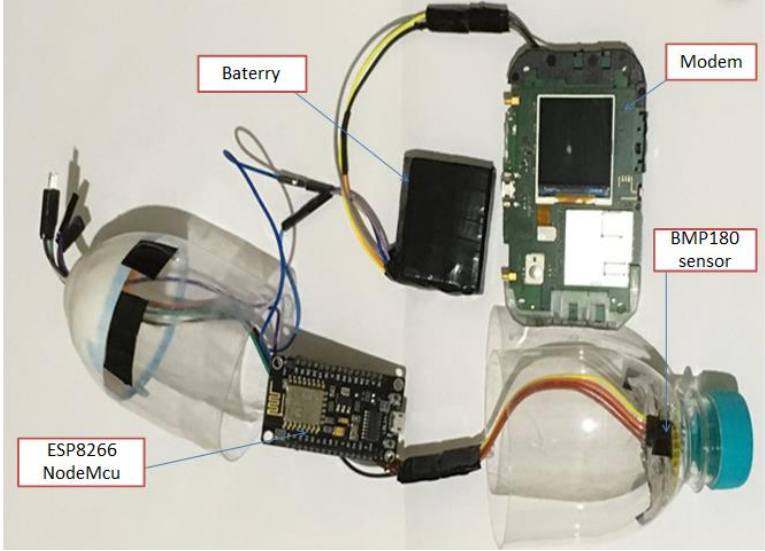

Figure 5. Parts of measurement system before installation

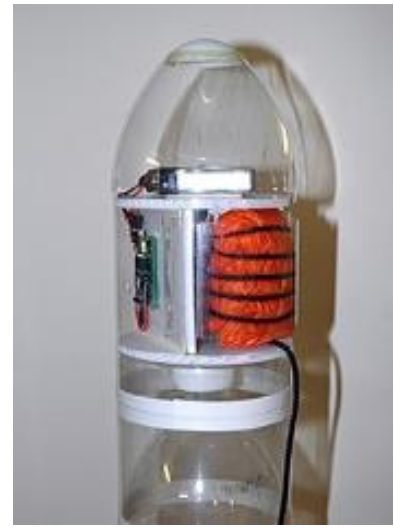

Figure 6. Measurement system in the payload

Table 4. Electronic Components

\begin{tabular}{|c|c|c|}
\hline $\mathrm{N}$ & Component & Quantity \\
\hline & NodeMcu & \\
\hline \multirow[t]{2}{*}{ U1 } & v3 ESP8266 & 1 \\
\hline & Wifi Module & \\
\hline \multirow[t]{2}{*}{ S1 } & $\begin{array}{c}\text { BMP180 } \\
\text { Sensor }\end{array}$ & 1 \\
\hline & Reed & \\
\hline \multirow[t]{2}{*}{ S2 } & Switch & 1 \\
\hline & $\begin{array}{l}\text { Sensor } \\
\text { Tower Pro }\end{array}$ & \\
\hline \multirow[t]{2}{*}{ J1 } & SG90 Servo & 1 \\
\hline & $\begin{array}{c}\text { Motor } \\
1000 \mathrm{mAh}\end{array}$ & \\
\hline \multirow{2}{*}{$\mathrm{P} 1$} & 3,7v Battery & 1 \\
\hline & $\begin{array}{c}2000 \mathrm{mAh} \\
3,7 \mathrm{v} \text { Battery }\end{array}$ & 1 \\
\hline L1 & $\begin{array}{l}\text { LED Red } \\
663 \mathrm{~nm}\end{array}$ & 1 \\
\hline SW & S & 1 \\
\hline
\end{tabular}

Figure 7. Electronic circuit design using fritzing

BMP180 Barometric sensor is an analog device from Bosch. It is the low-priced sensing resolution for expedient atmospheric pressure and heat. When the pressure is changes with altitude and also gets altimeter value $[16,17]$. BMP180 is an I2C standard device. It has four pin, SDA, SCL, VIN, and GND. SDA is connected to digital D1 pin of NodeMcu, SCL is connected to digital D2 pin of NodeMcu, VIN and GND are connected to 3.3V pin of NodeMcu as input power for BMP180 sensor [18]. Air pressure data from BMP180 sensor [19] is calculated in source code after uploading process into NodeMcu, and finally data will be sent to the cloud of ThingSpeak using a portable modem. In this research, vertical position detection in barometric altimetry performed by a single-device system [20].

Reed switch sensor is used for triggering initial time when water rocket just launch. It has two pin connected to D4 pin and 3.3 V of NodeMcu. The advantages of Reed switches that meet our requirement: (1) Ability to work in conditions of high humidity, dust with a low transition resistance in the closed position (0.01-0.001 ohm) and low voltage drop at the terminals; (2) Simplicity of design, low weight and compact dimensions, it allows to automate their production and lower manufacturing costs; (3) High speed (response time and release 1-3 $\mathrm{ms}$ ), that allows the use of reed switches with switching frequency up to $1000 \mathrm{~Hz}$; (4) The absence of rubbing parts and complex kinematic pairs ensures reliable operation of the reed switch within 106-109 cycles; (5) High dielectric strength between the contact gap [21]. 
This project research uses NodeMcu as a primary microcontroller. NodeMcu is an open-source firmware and development kit based on ESP8266 Wifi Module that supports to prototype Internet of Things (IOT) product [22]. IoT creates a smart environment by connecting microcontroller, sensors, and servo motor, and equip them with ability to gather and exchange data [23]. Low cost, Open source, Interactive, Programmable, Simple, Smart, and Wifi enabled are features of NodeMcu in three specific advantages: (1) Arduino-like hardware IO. (2) Nodejs style network API; and (3) Lowest cost Wi-fi. NodeMcu can be bought with the low cost \$5, comparison with Arduino Uno the predecessor open source hardware the price around \$12 and there is additional cost to buy Wifi shield. By using ESP8266 sensors data transmitted from rocket to the cloud through internet networks [24].

\section{Results and Analysis}

Five experiments had been conducted to see how the water rocket measurement system work in practice. Table 5 shows the result of the research. In the first experiment, Deployment system was tested. The location took place in the area of PP-IPTEK (Science Center). 100psi air pressure and $500 \mathrm{ml}$ water volume applied to the water rocket as the propulsion. The water rocket was launched in the weekdays to avoid traffic of people to visit the science center and sunset condition to avoid sunlight and wind pressure.The first experiment was focused on capability the Deployment System to release the parachute, Active state meant the system works well. In the second experiment, Altitude and Deployment system were measured. The values of air pressure and water volume remain the same. From the ThingSpeak Channel it showed 36 meter Altitude when the water rocket reached the Apogee, right after the rocket in Coasting Descent the parachute would be released automatically, so the deployment system worked successfully. Rockets flight dynamics characterization is essential in order to make it capable to move as expected [25].

Table 5. Result of Water Rocket Measurement System Experiment

\begin{tabular}{|c|c|c|c|c|c|c|c|c|}
\hline Experiment & Date & $\begin{array}{l}\text { Time } \\
\text { (WIB) }\end{array}$ & $\begin{array}{c}\text { Air } \\
\text { Pressure } \\
\text { (Psi) }\end{array}$ & $\begin{array}{c}\text { Water } \\
\text { Volume } \\
\text { (ml) }\end{array}$ & Location & $\begin{array}{l}\text { Altitude } \\
\text { (meter) }\end{array}$ & $\begin{array}{l}\text { Result } \\
\text { Velocity } \\
\text { (meter/s) }\end{array}$ & $\begin{array}{c}\text { Deployment } \\
\text { System }\end{array}$ \\
\hline 1 & $\begin{array}{l}\text { November } \\
\text { 30th, } 2017\end{array}$ & $16: 30$ & 100 & 500 & $\begin{array}{c}\text { PP- } \\
\text { IPTEK }\end{array}$ & - & - & Active \\
\hline 2 & $\begin{array}{l}\text { December } \\
14 \text { th, } 2017\end{array}$ & $16: 14$ & 100 & 500 & $\begin{array}{l}\text { PP- } \\
\text { IPTEK }\end{array}$ & 36 & - & Active \\
\hline 3 & $\begin{array}{l}\text { December } \\
29 \text { th, } 2017\end{array}$ & $16: 16$ & 100 & 500 & $\begin{array}{l}\text { PP- } \\
\text { IPTEK }\end{array}$ & 27.5 & - & Active \\
\hline 4 & $\begin{array}{l}\text { January } \\
11 \text { th, } 2018\end{array}$ & $16: 45$ & 100 & 500 & $\begin{array}{l}\text { PP- } \\
\text { IPTEK }\end{array}$ & 30 & - & Active \\
\hline 5 & $\begin{array}{l}\text { January } \\
\text { 18th, } 2018\end{array}$ & $16: 30$ & 100 & 500 & $\begin{array}{l}\text { PP- } \\
\text { IPTEK }\end{array}$ & 25.7 & 340.6 & Active \\
\hline
\end{tabular}

The third experiment was started on 04:16 PM, just two minutes late than two weeks ago. Water rocket and the launcher were placed in lauch pad in the same location. From Smartphone in the ThingSpeak Channel could be then displayed 27.5 meter of the changing value for Altitude. Fourth experiment was repeatition to the two prior experiments. The main focus was still on Altitude and Deployment System measurement to make sure meets expected repeatability. On ThingSpeak Channel noticed that 30 meter the water rocket to get Maximum Altitude Reach. When the water rocket on Coasting Descent position, the Deployment System was activated and parachute was released in minimum Altitude of 20 meters. Finally, fifth experiment was to complete Altitude, Velocity, and Deployment System measurement. Final experiment conducted on Thursday, January 18th 2018, time 04:30PM. Good weather condition to launch the water rocket at this afternoon. No different values for air pressure and water volume to set for consistency. The view from ThingSpeak Channel showed the values 25.7 meter for Altitude and 340.6 meter/s for Velocity. The Deployment System also worked well to release the parachute. Due to time limitation to do this research, the Velocity measurement was just taken one time, it is actually not enough. It needs at least five times to know the chosen 
method and sensor will be considered for the next step of research. However, the measurement of Altitude and Velocity have completed and the Deployment System worked as it is expected.

The Altitude vs Date from Thing Speak Channel can be seen at Figure 8. It shows the graphical presentation of the experiment on Table 5. The experiment 1-4 took data samples once in two weeks, data sample was taken in the next week for experiment 5 . Altitude values tends to decrease, it could be caused by the wind resistance, power of propulsion, elevation angle, and also the structure of nose. The Velocity vs Date from ThingSpeak Channel can be seen at Figure 9. Only one sample was taken to measure the velocity of water rocket. The goal is obtaining the maximum velocity in the Highest Velocity Range when the water rocket flies right after launching until reaching Powered Ascent Position. Of course it is important to have more data of Velocity to analyze, but this paper deals with the model of water rocket competition. That is way in the next research it is mandatory to deliver the technical aspect of this measurement.

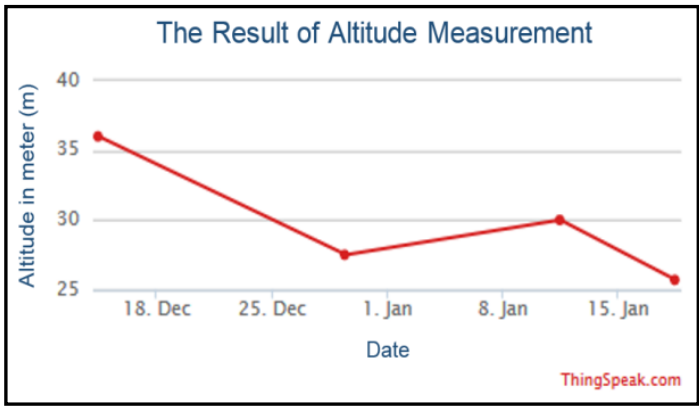

Figure 8. Altitude measurement

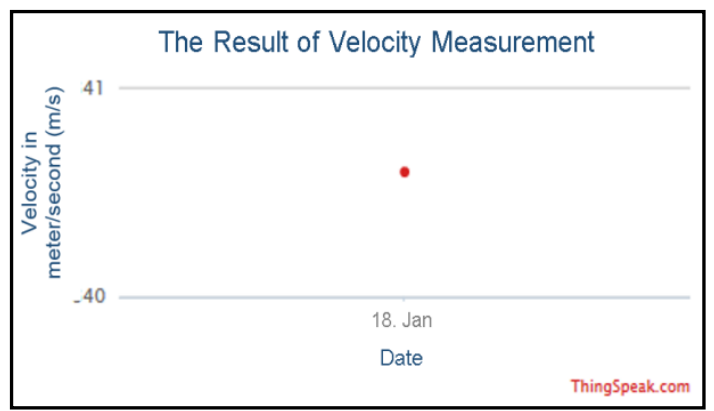

Figure 9. Velocity measurement

\section{Conclusion}

This study proposed AVP Model of Water Rocket competition. This model add Altitude, Velocity, and the Deployment System to release parachute automatically as criteria to collect the point. To support this model, the design of Water Rocket Measurement System based low cost NodeMcu installed in water rocket. This study found that the water rocket measurement system could calculate Altitude and Velocity, and Deployment System also could release the parachute automatically in minimum Altitude of 20 meters. Altitude and Velocity data fluctuation are stored in the cloud and can be viewed through ThingSpeak Channel that accessed from Smartphone. The limitation of this research, portable modem is used so it will contribute additional weight and size of the water rocket. Serial installation of two $1000 \mathrm{mAh}$ and $2000 \mathrm{mAh}$ $3,7 \mathrm{~V}$ batteries will cause inefficiency related to additional weight of the water rocket. However this proposed AVP model is enable to enrich STEM Education program especially in Water Rocket Activity.

\section{References}

[1] Gonzalez HB, Kuenzi JJ. Science, Technology, Engineering, and Mathematics (STEM) Education: A Primer. Federation of American Scientist. R42642. 2012.

[2] Egarievwe S. Vertical Education Enhancement-A Model for Enhancing STEM Education and Research. Global Conference on Contemporary Issues in Education (GLOBE-EDU) Procedia - Social and Behavioral Sciences. Las Vegas. 2015; 177: 336-344.

[3] NASA. Adventures in Rocket Science. Alabama. The NASA Explorer Institute (NEI). 2008.

[4] Nur Hidayat M, Surur I, Wahyu Cahya Ningsih S, Fitri Sarah D. Science Center Annual Report 2015. PP-IPTEK. 2015.

[5] Nur Hidayat M, Surur I, Wahyu Cahya Ningsih S, Fitri Sarah D. Science Center Annual Report 2016. PP-IPTEK. 2016.

[6] Nur Hidayat M, Surur I, Wahyu Cahya Ningsih S, Fitri Sarah D. Science Center Annual Report 2017. PP-IPTEK. 2017.

[7] SEWG [Online]. APRSAF-25 Water Rocket Competition Event. URL: https://www.aprsaf.org/working_groups/se/. Retrieved $16^{\text {th }}$ May 2018. 
[8] NASA [Online]. Rocket Research 101. URL: https://www.grc.nasa.gov/www/k12/rocket/BottleRocket/journey101thrust.htm. Retrieved $18^{\text {th }}$ May 2018.

[9] Malek YN, Kharbouch A, El Khoukhi H, Bakhouya M, De Florio V, El Ouadghiri D, Latré S, Blondia C. On the use of IoT and big data technologies for real-time monitoring and data processing. Procedia computer science. 2017; 113: 429-434.

[10] Haubenwaller AM, Vandikas K. Computations on the edge in the internet of things. Procedia Computer Science. 2015; 52: 29-34

[11] Škraba A, Koložvari A, Kofjač D, Stojanović R, Stanovov V, Semenkin E. Streaming pulse data to the cloud with bluetooth LE or NodeMcu ESP8266. IEEE 5 ${ }^{\text {th }}$ Mediterranean Conference on Embedded Computing (MECO). 2016.

[12] ThingSpeak [Online]. Understand Your Things. URL: https://thingspeak.com/. Retrieved $17^{\text {th }}$ June 2018.

[13] Mehta R, Sahni J, Khanna K. Internet of Things: Vision, Applications and Challenges. Procedia Computer Science. 2018; 132: 1263-1269.

[14] Abdul Rahman A, Graves CA. Internet of Things Application using Tethered MSP430 to Thingspeak Cloud. IEEE Symposium on Service-Oriented System Engineering. 2016: 352-357.

[15] Mhatre L, Rai N. Integration between Wireless Sensor and Cloud. IEEE International conference on I-SMAC (IoT in Social, Mobile, Analytics and Cloud). 2017: 779-782.

[16] Agrawal P, Chitranshi G. Internet of Things for Monitoring the Environmental Parameters. IEEE International Conference on Information Technology (INCITe)-The Next Generation IT Summit. 2016: 48-52.

[17] Stamatescu G, Stamatescu I, Popescu D, Mateescu C. Sensor Fusion Method for Altitude Estimation in Mini-UAV Applications. IEEE International Conference $7^{\text {th }}$ Edition Electronics, Computers, and Artificial Intelligence (ECAI). 2015: 39-41.

[18] Kodali RK, Mandal S. IOT Based Weather Station. IEEE International Conference on Control, Instrumentation, Communication, and Computational Technologies (ICCICCT). 2016: 680-683.

[19] Setiyono B, Sumardi, Harisuryo R. Measurement System of Temperature, Humidity and Air Pressure over $433 \mathrm{MHz}$ Radio Frequency: An Application on Quadrotor. IEEE $2^{\text {nd }}$ International Conference on Information Technology, Computer and Electrical Engineering (ICITACEE). 2015; 438-441.

[20] Bolanakis DE, Laopoulos T. On the Evaluation of Contemporary Commercial Barometric Pressure Sensors for Altitude Measurements. The 9th IEEE International Conference on Intelligent Data Acquisition and Advanced Computing Systems: Technology and Applications. Bucharest. 2017; 1: 459-464.

[21] Dmitriev SV, Dmitrieva IS, Syutkina JP. The Reliability of the Contact Switching of the Measuring Signal. IEEE $2^{\text {nd }}$ International Conference on Industrial Engineering, Applications and Manufacturing (ICIEAM). 2016.

[22] NodeMcu [Online]. NodeMcu Connect Things Easy. URL: http://nodemcu.com/index_en.html. Retrieved $20^{\text {th }}$ May 2018.

[23] Kahsyap M, Sharma V, Gupta N. Taking MQTT and NodeMcu to loT: Communication in Internet of Things. Procedia Computer Science. 2018; 132: 1611-1618.

[24] Yuliandoko H, Wardhany VA, Pramono SH, Siwindarto P. Design of Flooding Detection System Based on Velocity and Water Level DAM with ESP8266. IEEE $2^{\text {nd }}$ International Conferences on Information Technology, Information Systems and Electrical Engineering (ICITISEE). 2017.

[25] Musa P, Christie DA, Wibowo EP. An Implementation of Direction Cosine Matrix in Rocket Payload Dynamics Attitude Monitoring. IEEE International Conference on Informatics and Computing (ICIC). 2016. 